\title{
THE EFFECT OF pH CHANGES AND IONIZATION ON THE ACTION OF EPINEPHRINE UPON THE ISOLATED RABBIT ILEUM ${ }^{\dagger}$
}

\author{
Robert C. REYNOLDS* and Harold F. HARDMAN** \\ Department of Pharmacology, University of Michigan, Ann Arbor, Michigan, U.S.A.
}

Received 20 March 1972

Accepted 26 June 1972

R.C. REYNOLDS and H.F. HARDMAN, The effect of pH changes and ionization on the action of epinephrine upon the isolated rabbit ileum, European J. Pharmacol. 20 (1972) 249-255.

This study demonstrates that the activity of epinephrine on the isolated rabbit ileum is related to the quantity of epinephrine present as the cation in the tissue bath at a given $\mathrm{pH}$. Isolated segments of rabbit ileum were exposed to doses of epinephrine in Tyrode solution which varied in $\mathrm{pH}$ from 6.4 to 8.8 . The change of $\mathrm{pH}$ did not significantly alter the spontaneous contractile activity of an intestinal segment; however, epinephrine-induced inhibition of intestinal activity varied with changes of $\mathrm{pH}$. At $\mathrm{pH} \mathrm{6.4-7.8} \mathrm{the} \mathrm{catecholamines} \mathrm{exist} \mathrm{predominantly} \mathrm{as} \mathrm{cations.} \mathrm{The}$ relative amount of the cationic form of these compounds does not appreciably change unless the pH of a solution of catecholamine is raised above 7.8. The alteration of $\mathrm{pH}$ from 7.8 to 8.8 was great enough to vary the fraction of epinephrine present as a cation from 90 to $52 \%$ of a given total dose of drug. As the pH was raised above 7.8 , epinephrine activity decreased in proportion to the decreased concentration of epinephrine cation.

$\begin{array}{lll}\text { Epinephrine } & \text { Ionization } & \text { Rabbit ileum }\end{array}$

\section{INTRODUCTION}

The ionization of the sympathomimetic amines has been studied by numerous investigators with the hope of explaining the differences in pharmacological activities of these compounds on the basis of differences in ionization. In order to determine the possible relationship between ionization and biological activity, Leffler et al. (1951), Lewis (1954) and Tuckerman et al. (1959) compared the activities of different sympathomimetic amines on various test preparations. In studying dog blood pressure, rabbit uterus, or rabbit intestine, no significant correlation could be made between the different ionization constants of these drugs and their various activities at a constant $\mathrm{pH}$. The present investigation is concerned with the

$\dagger$ This work was supported by a grant from the Michigan Heart Association and by U.S.P.H.S. Grant H-3931.

* Present address: Department of Anesthesia, University of Pennsylvania School of Medicine, Philadelphia, Pennsylvania 19104, U.S.A.

** Present address: Department of Pharmacology, Medical College of Wisconsin, Milwaukee, Wisconsin, U.S.A. effects of alterations of $\mathrm{pH}$ and ionization on the activity of a single sympathomimetic amine, epinephrine.

Three groups in the catecholamine molecule are capable of undergoing ionization. Lewis (1954) presented spectrophotometric and potentiometric evidence that one of the phenolic hydroxyl groups on the catechol ring of epinephrine has a $\mathrm{p} K_{\mathrm{a}}$ of 8.71 and that the amino group has a $\mathrm{p} K_{\mathrm{a}}$ of 9.90 . A third point of ionization, the second hydroxyl phenolic group, has a $\mathrm{p} K_{\mathrm{a}}$ value above 12.0 and, therefore, is present in the non-ionized form at all $\mathrm{pH}$ values at which the catecholamines are known to have biological activity. Using the $\mathrm{p} K_{\mathrm{a}}$ values determined by Lewis, it can be calculated that epinephrine (as well as norepinephrine and isoproterenol) exists as approximately $95 \%$ cation, $4 \%$ zwitterion and $1 \%$ anion and undissociated molecule at $\mathrm{pH} 7.5$. This relationship of the four ionic species of epinephrine does not change appreciably until the $\mathrm{pH}$ is raised above 8.0 . The relative amounts of the four forms of epinephrine at different $\mathrm{pH}$ 's are shown in fig. 1 .

In addition to reporting a large series of carefully 


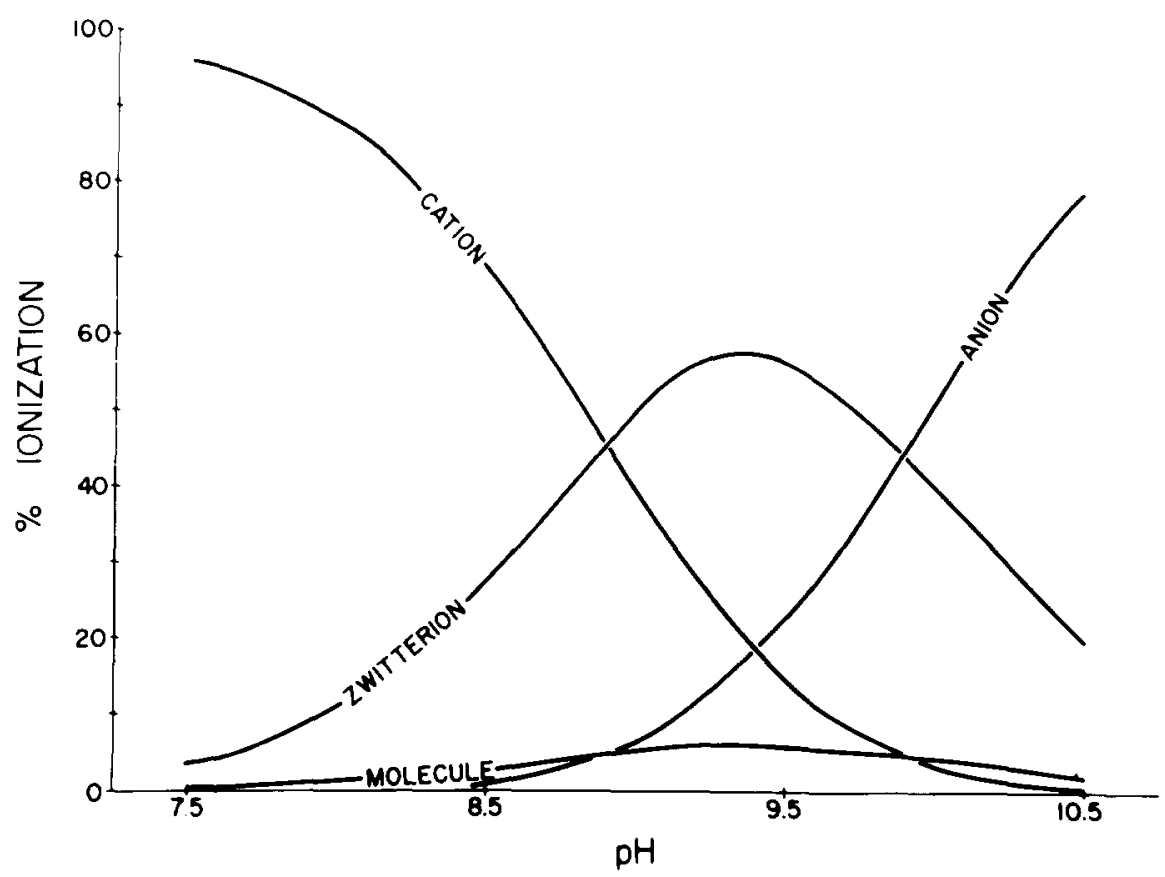

Fig. 1. The ionization of epinephrine. A graphic representation of the relative amounts of the different ionic forms of epinephrine at $\mathrm{pH}$ 7.5-10.5 calculated from the data of Lewis (1954): $\mathrm{p} K_{\mathrm{a}_{1}}$ (phenolic) 8.71, $\mathrm{p} K_{\mathrm{a}_{2}}$ (amino) 9.90. Epinephrine cation has a single positive charge on the amine side chain. The anion has a single negative charge on one of the phenolic hydroxyl groups of the catechol ring. The zwitterion has a positive and a negative charge, and the molecule has no charge.

determined ionization constants for a number of sympathomimetic amines, Lewis attempted to identify the active ionic form of some of the sympathomimetic amines by testing the compounds at varying $\mathrm{pH}$ values on an isolated rabbit uterus or intestinal segment. He reported that he was not able to alter the $\mathrm{pH}$ of the medium surrounding his biological test tissues to a degree sufficient to produce a significant change in the relative activities of the compounds that he tested, without producing irreversible changes in his preparation.

We have observed that by gradually increasing the $\mathrm{pH}$ of the bathing solution of an isolated segment of rabbit ileum, it was possible to vary the $\mathrm{pH}$ of this preparation from $\mathrm{pH} 7.4$ to 8.8 or from $\mathrm{pH} 7.4$ to 6.4 without significantly altering the spontaneous contractile activity of the intestinal segment. Under these circumstances the fraction of epinephrine cation present at a given dose of drug can be varied from greater than $99-52 \%$. This change in the degree of ionization should be adequate to determine whether the cationic form of epinephrine is the form of the drug which produces relaxation of the intestinal smooth muscle.

\section{MATERIALS AND METHODS}

\subsection{General}

Young fasted rabbits weighing $2.2-2.6 \mathrm{~kg}$ were killed with a swift blow on the head, and segments of ileum $3-4 \mathrm{~cm}$ long were immediately removed and suspended in Tyrode solution maintained at $37.5 \pm$ $0.5^{\circ} \mathrm{C}$. Spontaneous contractions were recorded on a smoked kymograph paper with an isotonic frontal writing lever. Tensions of $0.5-1.0 \mathrm{~g}$ were imposed on each intestinal segment in order to permit a maximum excursion of the writing point with a constant base line. Only spontaneously contracting intestinal segments, which produced regular excursions of the recording lever of more than $40 \mathrm{~mm}$, were used in these experiments.

The Tyrode solution had the following composition (M): $0.137 \mathrm{NaCl}, 0.0027 \mathrm{KCl}, 0.0043 \mathrm{NaHCO}_{3}$, $0.0025 \mathrm{CaCl}_{2}, 0.001 \mathrm{NaH}_{2} \mathrm{PO}_{4}, 0.002 \mathrm{MgCl}_{2}$ and 
0.0055 glucose. All solutions were prepared with water deionized with a Barnstead Bantam Standard Demineralizer. When this solution was bubbled with a mixture of $95 \% \mathrm{O}_{2}-5 \% \mathrm{CO}_{2}$, it had a pH of 7.6 . Adjustments of $\mathrm{pH}$ were made by adding $1 \mathrm{~N} \mathrm{NaOH}$ or $1 \mathrm{~N} \mathrm{HCl}$ to the solution. All $\mathrm{pH}$ measurements were made with a Beckman Zeromatic $\mathrm{pH}$ meter while the solutions were exposed to an atmosphere of $95 \% \mathrm{O}_{2}-5 \% \mathrm{CO}_{2}$.

For each experiment freshly prepared solutions of crystalline 1-epinephrine (Mann Research Laboratories) were prepared in acidified ( $\mathrm{pH}$ about 6.5) Тyrode solution. The drug solution was added in less than $0.5-\mathrm{ml}$ quantities to the $30-\mathrm{ml}$ tissue bath. The final concentration of epinephrine in the bath was $0.001-0.01 \mu \mathrm{g} / \mathrm{ml}$. This range of drug concentration produced $40-100 \%$ depression of the spontaneous activity of an isolated segment of ileum.

At the beginning of each experiment, the $\mathrm{pH}$ of the Tyrode solution was 7.4. 2 different doses of epinephrine were used in all experiments. A dose of epinephrine, which produced between 80 and $95 \%$ depression of intestinal contraction at $\mathrm{pH} 7.4$ was first determined. The effect of a dose of epinephrine, onethird to one-half of the amount of this established high dose, was then measured. This procedure provided an indication of the sensitivity of each intestinal segment. Only those segments of ileum which proved to have an appreciable sensitivity to this variation of epinephrine dosage were used in these experiments.

When a dose of epinephrine had produced its maximum depression of intestinal activity, the bath was emptied and fresh solution was added. The next dose of drug was added to the bath only after the activity of the ileum had returned to its pre-inhibition level. 4-8 tests were performed with each dose of the drug.

After the sensitivity of an intestinal segment had been established at $\mathrm{pH} 7.4$, Tyrode solution with a slightly higher or lower $\mathrm{pH}$ was admitted to the bath and the same procedure was followed at this new $\mathrm{pH}$. The $\mathrm{pH}$ of the Tyrode solution was changed gradually, 0.2 or $0.4 \mathrm{pH}$ unit at a time from $\mathrm{pH} 7.4$ to 8.8 , or from 7.4 to 6.4 .

\subsection{Statistical analyses}

Control amplitudes of contraction were determined as the mean of four contractions just prior to each addition of epinephrine to the tissue bath. The lowest experimental amplitude of contraction produced by each addition of epinephrine was measured and the percent of inhibition of the control amplitude was determined. 4-8 tests were performed with each dose of the drug at every $\mathrm{pH}$ tested. Since the sensitivity of the intestinal preparations varied considerably, each intestinal segment could be compared only to itself. It was not possible to perform group comparisons with data of this type.

\section{RESULTS}

At the beginning of each experiment, repeated additions of 2 concentrations of epinephrine were added to the tissue bath. When the preparation was stabilized and showed consistent responses to epinephrine at $\mathrm{pH} \mathrm{7.4,} \mathrm{the} \mathrm{pH}$ of the Tyrode solution was raised or lowered and the responses of the tissue to the same concentrations of epinephrine were measured. Fig. 2 shows sample portions of a kymograph tracing of a typical experiment in which the $\mathrm{pH}$ of Tyrode solution was raised from $\mathrm{pH} 7.4$ to 8.8 . The occasional high sweeps of the writing lever, which follow a depression of the intestinal segment with a dose of epinephrine, are artifacts produced by the changing of the tissue bath fluid.

The complete results of the experiment shown in fig. 2 are tabulated in table 1 and are presented in graphic form in part A of fig. 3. Results of 3 experiments similar to the experiment shown in table 1 and fig. 2 are presented in fig. 3, B-D. Table 1 indicates that, if the total dose of epinephrine in the Tyrode solution is held constant as the $\mathrm{pH}$ of the tissue bath

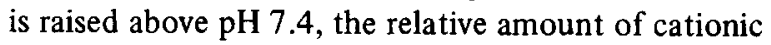
epinephrine is decreased. In addition, the graphs (fig. 3) demonstrate that the effect of a constant total dose of epinephrine decreases in proportion to the reduction of the concentration of epinephrine cation. By raising the total dose of epinephrine in the tissue bath at $\mathrm{pH} 8.6$ or 8.8 , it was possible to expose the tissue to the same concentration of cationic epinephrine that was present in the bath at $\mathrm{pH} 7.4$. The amount of depression produced by this dose of epinephrine at the higher pH's was never significantly different from the depression produced at the beginning of the experiment with the same concentra- 
$\mathrm{pH} 7.4$

pH 7.4

pH 7.8

$\mathrm{pH} 8.2$

$\mathrm{pH} 8.6$

pH 8.8

pH 8.8

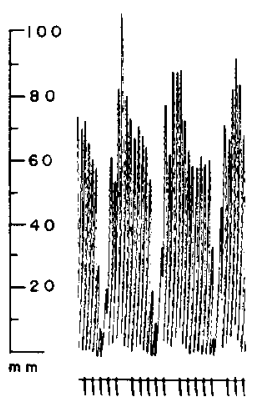

$\uparrow \uparrow \uparrow$

$0.2 \mathrm{Ng}$

$0 \mathrm{~min}$

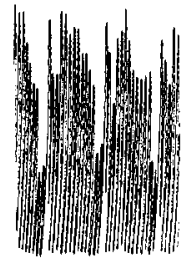

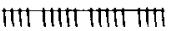

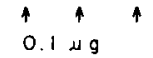

$6 \mathrm{~min}$

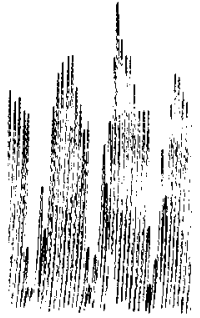

IITIIII IIIIIIIIIT

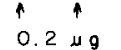

$37 \mathrm{~min}$

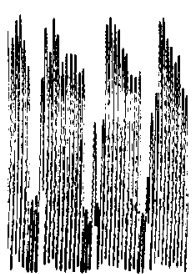

तIIIIIIIIIIIIIII

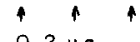

$54 \mathrm{~min}$

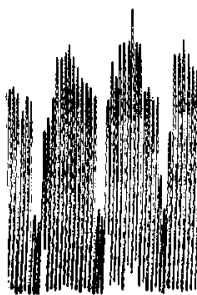

"IIIII IIIII IIIITII

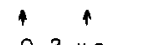

$72 \mathrm{~min}$

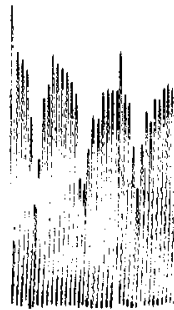

IIIIIIII IIIII III

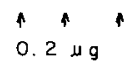

$89 \mathrm{~min}$

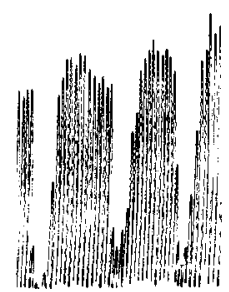

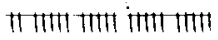

4.424

$98 \mathrm{~min}$

Fig. 2. Portions of a kymograph tracing of epinephrine depression of rabbit ileum: experiment A. Doses of epinephrine (0.2, 0.1 and $0.42 \mu \mathrm{g}$ ) were added to the isolated tissue bath at the points indicated by the arrows. As soon as the maximum amount of depression was produced by a dose of epinephrine, the Tyrode solution of the bath was changed. The $\mathrm{pH}$ of the bath is indicated

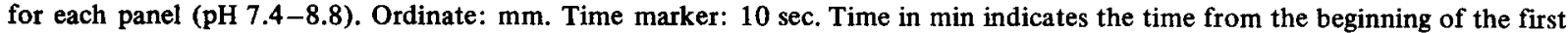
panel to the beginning of each subsequent panel. The complete results of this experiment are tabulated in table 1 and presented graphically in part A of fig. 3 .
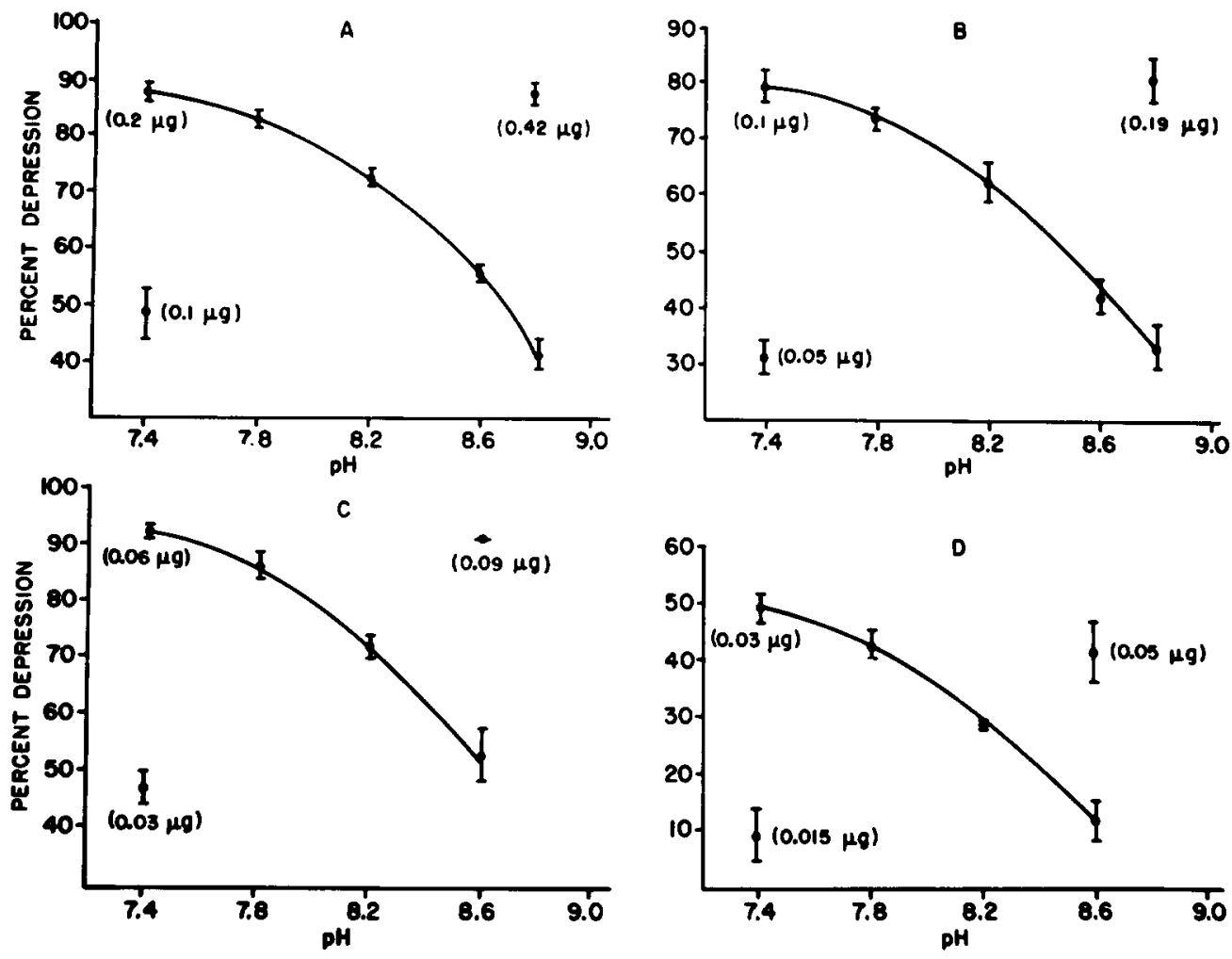

Fig. 3. Epinephrine depression of rabbit ileum, pH 7.4-8.8. Experiments A-D. 
Table 1

Epinephrine depression of rabbit ileum.

\begin{tabular}{|c|c|c|c|c|c|c|}
\hline $\mathrm{pH}$ & $\begin{array}{l}\text { Total dose } \\
\text { of epi. } \\
(\mu \mathrm{g})\end{array}$ & $\begin{array}{l}\text { Cation dose } \\
\text { of epi. } \\
(\mu \mathrm{g})\end{array}$ & $\begin{array}{l}\text { Control } \\
\text { amplitude } \\
(\mathrm{mm}) \\
( \pm \text { S.E.M.) }\end{array}$ & $\begin{array}{l}\text { Experimental } \\
\text { amplitude } \\
(\mathrm{mm}) \\
( \pm \text { S.E.M.) }\end{array}$ & $\begin{array}{l}\text { Number of } \\
\text { experimental } \\
\text { observations } \\
n\end{array}$ & $\begin{array}{l}\text { Percent } \\
\text { depression } \\
( \pm \text { S.E.M. })\end{array}$ \\
\hline 7.4 & 0.2 & 0.19 & $60 \pm 0.8$ & $7 \pm 1.1$ & 4 & $88 \pm 1.7$ \\
\hline 7.4 & 0.1 & 0.09 & $60 \pm 0.8$ & $30 \pm 2.4$ & 6 & $49 \pm 4.0$ \\
\hline 7.8 & 0.2 & 0.18 & $60 \pm 1.3$ & $10 \pm 0.6$ & 4 & $83 \pm 0.6$ \\
\hline 8.2 & 0.2 & 0.16 & $61 \pm 1.0$ & $16 \pm 0.6$ & 7 & $73 \pm 0.9$ \\
\hline 8.6 & 0.2 & 0.13 & $59 \pm 0.7$ & $26 \pm 0.6$ & 4 & $56 \pm 0.9$ \\
\hline 8.8 & 0.2 & 0.10 & $60 \pm 1.4$ & $35 \pm 1.5$ & 6 & $41 \pm 2.4$ \\
\hline 8.8 & 0.42 & 0.19 & $60 \pm 1.4$ & $7 \pm 1.2$ & 4 & $87 \pm 2.0$ \\
\hline
\end{tabular}

Table 2

Epinephrine depression of rabbit ileum.

pH $7.4-6.4$, experiments $\mathrm{E}-\mathrm{H}$.

\begin{tabular}{|c|c|c|c|c|c|c|c|c|c|c|c|c|}
\hline \multirow[t]{2}{*}{$\mathrm{pH}$} & \multicolumn{3}{|c|}{ Experiment $\mathrm{E}$} & \multicolumn{3}{|c|}{ Experiment $F$} & \multicolumn{3}{|c|}{ Experiment G } & \multicolumn{3}{|c|}{ Experiment $\mathrm{H}$} \\
\hline & $\begin{array}{l}\text { Total } \\
\text { dose } \\
\text { of epi. } \\
(\mu g)^{1}\end{array}$ & $n$ & $\begin{array}{l}\text { Percent } \\
\text { depression } \\
( \pm \text { S.E.M. })\end{array}$ & $\begin{array}{l}\text { Total } \\
\text { dose } \\
\text { of epi. } \\
(\mu g)^{2}\end{array}$ & $n$ & $\begin{array}{l}\text { Percent } \\
\text { depression } \\
( \pm \text { S.E.M. })\end{array}$ & $\begin{array}{l}\text { Total } \\
\text { dose } \\
\text { of epi. } \\
(\mu g)^{2}\end{array}$ & $n$ & $\begin{array}{l}\text { Percent } \\
\text { depression } \\
( \pm \text { S.E.M.) }\end{array}$ & $\begin{array}{l}\text { Total } \\
\text { dose } \\
\text { of epi. } \\
(\mu g)^{1}\end{array}$ & $n$ & $\begin{array}{l}\text { Percent } \\
\text { depression } \\
( \pm \text { S.E.M. })\end{array}$ \\
\hline 7.4 & 0.3 & 6 & $82 \pm 1.2$ & 0.1 & 6 & $36 \pm 2.1$ & 0.1 & 6 & $24 \pm 1.2$ & 0.3 & 8 & 100 \\
\hline 7.0 & 0.3 & 7 & $82 \pm 1.9$ & 0.1 & 5 & $39 \pm 2.7$ & 0.1 & 7 & $21 \pm 2.8$ & 0.3 & 6 & 100 \\
\hline 6.8 & 0.3 & 5 & $82 \pm 2.0$ & 0.1 & 4 & $36 \pm 2.6$ & 0.1 & 5 & $22 \pm 4.1$ & 0.3 & 4 & 100 \\
\hline 6.6 & 0.3 & 5 & $80 \pm 0.7$ & 0.1 & 5 & $40 \pm 2.5$ & 0.1 & 4 & $23 \pm 4.7$ & 0.3 & 4 & $96 \pm 1.3$ \\
\hline 6.4 & 0.3 & 7 & $82 \pm 1.5$ & 0.1 & 5 & $37 \pm 3.0$ & & & & & & \\
\hline
\end{tabular}

${ }^{1}$ Total dose of epinephrine: $0.3 \mu \mathrm{g}$ equals $0.29 \mu \mathrm{g}$ cationic epinephrine, $\mathrm{pH} 7.4-6.4$.

${ }^{2}$ Total dose of epinephrine: $0.1 \mu \mathrm{g}$ equals $0.097 \mu \mathrm{g}$ cationic epinephrine, $\mathrm{pH} 7.4-6.4$.

tion of epinephrine cation at the lower $\mathrm{pH}$. In other words, epinephrine activity upon the isolated rabbit ileum paralleled the concentration of epinephrine cation present in the tissue bath at a given $\mathrm{pH}$.

Data obtained from experiments, in which the $\mathrm{pH}$ of the Tyrode solution bathing 4 intestinal segments was lowered from $\mathrm{pH} 7.4$ to 6.6 or 6.4 , are shown in table 2. This change of $\mathrm{pH}$ produces no appreciable alteration in the ionization of epinephrine; therefore, the percent of cationic epinephrine remains the same as the $\mathrm{pH}$ is lowered below 7.4. Similarly, this change of $\mathrm{pH}$ does not change significantly the activity of a constant total dose of epinephrine on the isolated rabbit intestinal segment.

\section{DISCUSSION}

Several factors made the isolated segment of rabbit ileum a choice preparation for studying the effects of $\mathrm{pH}$ changes on the action of epinephrine. First, and most important, this mammalian tissue preparation is capable of withstanding variation of $\mathrm{pH}$ great enough to provide appreciable alterations in the ionization of 
epinephrine. The lack of variation of the amplitude and rate of contraction of this preparation, in spite of variations of $\mathrm{pH}$ from 7.4 to 8.8 or 6.4 , has been illustrated in previous sections. Secondly, the rabbit ileum is highly sensitive to change in the concentration of epinephrine. Burn (1950) demonstrated that with this preparation it is possible to distinguish doses of epinephrine differing by as little as $10 \%$. This degree of sensitivity, combined with the stability of the preparation, made it possible to detect the variations in concentrations of the active form of epinephrine caused by changes of ionization. An additional advantage of the rabbit ileum preparation is the fact that it is possible to make repeated, reproducible observations of the effect of a dose of epinephrine upon a single preparation.

The major disadvantage of the preparation is that different segments of ileum vary in sensitivity to epinephrine. This variation made it impossible to group the results from one preparation with those from another. Therefore, it was necessary to establish the range of sensitivity of each intestinal segment at the beginning and conclusion of an experiment. The fact that each intestinal segment responded consistently to repeated administration of epinephrine minimized this shortcoming of the preparation.

In a previous study of the isolated rabbit ileum, Ahlgren (1930) reported that he was unable to demonstrate any difference in epinephrine activity between $\mathrm{pH} 7.1$ and 7.7. The observations presented here agree with the previous report of Ahlgren; however, in this study the $\mathrm{pH}$ of the tissue bath was increased enough to produce an appreciable alteration in the ionization of epinephrine. It is evident from the data presented, that the response of the isolated segment of rabbit ileum to epinephrine is dependent upon the cationic concentration of the drug in the tissue bath. Significant variations in the activity of a constant total dose of epinephrine occur only when the alteration of the $\mathrm{pH}$ of the Tyrode solution produces a change in the ionization of the drug. Decreasing the $\mathrm{pH}$ of the tissue bath below 7.4 produces no significant change of epinephrine ionization and no alteration of epinephrine activity. Increasing the $\mathrm{pH}$ of a solution of epinephrine produces a decrease in the fraction of epinephrine present in the solution as cation, as well as a marked increase in the proportion of epinephrine existing as zwitterion. This same change of $\mathrm{pH}$ produces a decrease in the activity of a constant total dose of epinephrine added to the tissue bath. The most obvious interpretation could be that the decrease in epinephrine activity is caused by a decrease in the concentration of cationic epinephrine. In other words, the development of a negative charge on one of the phenolic hydroxyl groups of the catechol ring makes the drug inactive.

It is possible that the action of epinephrine could be inhibited by the increased concentration of epinephrine zwitterion. If the total dose of epinephrine is increased to prevent a decrease in the cationic concentration of epinephrine in the perfusion solution as the $\mathrm{pH}$ is raised from 7.4 to 8.8 , epinephrine activity is unchanged. This increase in the total dose of epinephrine also increases the concentration of epinephrine zwitterion. Since in all of the experiments there is no significant variation in the effect of a constant concentration of epinephrine cation, even though the $\mathrm{pH}$ of the test preparation is varied, we can rule out the possibility that zwitterion epinephrine acts as an inhibitor.

One additional explanation for the decrease in the activity of epinephrine with an increase in pH could be that the added epinephrine may have been destroyed more rapidly by auto-oxidation in the more alkaline $\mathrm{pH}$ range. Previously reported studies by Reynolds and Haugaard (1967) presented evidence that alkaline ( $\mathrm{pH} \mathrm{7.8)} \mathrm{solutions} \mathrm{of} \mathrm{epinephrine} \mathrm{re-}$ tained their ability to stimulate in vitro skeletal muscle phosphorylase for periods of $20-30 \mathrm{~min}$. This is considerably longer than the $50 \mathrm{sec}$ half-life of norepinephrine in comparable EDTA-free solutions reported by Crout et al. (1962). A possible explanation for this difference in the duration of activity of these catecholamine solutions could be that the solutions described here and in the study by Reynolds and Haugaard (1967) were prepared with deionized water which may have been freer of heavy metal contaminates than the preparations reported by Crout et al. (1962). It seems unlikely that the oxidation of epinephrine could account for the diminished activity within 5-10 sec after the drug had been added to the tissue bath.

The possibility that epinephrine could be more rapidly inactivated by the intestinal segments at higher $\mathrm{pH}$ values could not be ruled out by these experiments. However, studies of the effects of alkalosis 
and the actions of catecholamines in other isolated tissues do not support this hypothesis. In contrast to these experiments with isolated rabbit ileum, studies of the effects of alterations in $\mathrm{pH}$ on the inotropic and metabolic responses of isolated rat and turtle hearts (Hardman and Reynolds, 1965; Reynolds and Haugaard, 1967) demonstrated an enhancement of the activity of epinephrine with increases of $\mathrm{pH}$ values from 6.9 to 7.8 . Since the relative amounts of the four ionic species of epinephrine are not appreciably altered by changes of $\mathrm{pH}$ in this range, it was concluded that the variation of epinephrine activity in heart could not be ascribed to changes in drug ionization, but represented an effect of $\mathrm{pH}$ changes on cellular receptor mechanisms. If these conclusions are correct, it is evident that there must be a difference in the manner in which epinephrine receptors respond to changes of $\mathrm{pH}$. Cardiac catecholamine receptors appear to increase in their response to epinephrine as the $\mathrm{pH}$ is raised above 7.2 ; however, the receptors associated with epinephrine-induced intestinal activity are not affected by the same changes of $\mathrm{pH}$.

\section{REFERENCES}

Ahlgren, G., 1930, Über die Einwirkung von Kohlensauer, Bikarbonate und $\mathrm{H}$-ionkonzentration auf überlebende Organe und ihre Beeinflussbarkeit durch Pharmaka. Ein Beitrag zur Frage der Zusammensetzung der Serumsalzlösung, Skand. Arch. Physiol. 59, 1.

Burn, J.H., 1950, Biological Standardization, 2nd ed. (Oxford University Press, London).

Crout, S.R., A.J. Muskus and U. Trendelenburg, 1962, Effect of tyramine on isolated guinea-pig atria in relation to their noradrenaline stores, Brit. J. Pharmacol, 18, 600.

Hardman, H.F. and R.C. Reynolds, 1965, An effect of pH upon epinephrine inotropic receptors in the turtle heart, J. Pharmacol. Exptl. Therap. 149, 219.

Leffler, E.B., H.M. Spencer and A. Burger, 1951, Dissociation constants of adrenergic amines, J. Amer. Chem. Soc. 73 , 2611.

Lewis, G.P., 1954, The importance of ionization in the activity of sympathomimetic amines, Brit. J. Pharmacol. 9, 488.

Reynolds, R.C. and N. Haugaard, 1967, The effect of variations of $\mathrm{pH}$ upon the activation of phosphorylase by epinephrine in perfused contracting heart muscle, liver slices and skeletal muscle, J. Pharmacol. Exptl. Therap. 32, 417.

Tuckerman, M.M., J.R. Mayer and F.C. Nachod, 1959, Anomalous $\mathrm{p} K_{\mathrm{a}}$ values of some substituted phenylethylamines, J. Amer. Chem. Soc. 81, 92. 